\title{
THE WRITTEN ORATOR \\ OF "SONG OF MYSELF": \\ A Recent Trend in Whitman Criticism
}

MARK BAuerLein

\begin{abstract}
I.
What living and buried speech is always vibrating here ...

-Whitman, "Song of Myself"
\end{abstract}

What drops of all the sea of our science are baled up! and by what accident it is that these are exposed, when so many secrets sleep in nature! Hence the necessity of speech and song; hence these throbs and heart-beatings in the orator, at the door of the assembly, to the end namely that thought may be ejaculated as Logos, or Word.

-Emerson, "The Poet"

Through me forbidden voices,

Voices of sexes and lusts. . . . voices veiled, and I remove the veil,

Voices indecent by me clarified and transfigured ... .

-Whitman, "Song of Myself"

THE CRITICAL BELIEF that Whitman's poetry, specifically "Song of Myself," bespeaks an oratorical presence has persisted from Whitman's own time (fostered mainly by Whitman himself ${ }^{1}$ ) down to the present day. To confirm the prevalence of an oracular, "bardic" interpretation one need only consult a comprehensive bibliography of Whitman criticism and count the number of times the word "voice" or its variants appear in the titles of entries. ${ }^{2}$ Traditionally, most critics have argued for orality in Whitman either by examining his biography to show his sincere but unfulfilled intentions of building a career as a public speaker; ${ }^{3}$ or they have looked directly at the poetry to discover the rhetorical and stylistic patterns that bring to mind oral discourse. ${ }^{4}$ But recently some critics of "Song of Myself" have chosen to go beyond biographical and stylistic analyses alone to support their contentions for orality. In speaking of Whitman as the oracular poet, several critics in the last five years-notably John T. Irwin, Calvin Bedient, and C. Carroll Hollis ${ }^{5}$ - have used discourses outside the literary institution such as nuclear physics, analytic philosophy, and cultural anthropology. But notwithstanding how diverse are the aims of these disciplines, they all have served to clarify Whitman's place in oral tradition.

Whitman himself initiated the emphasis on speech in "Song of Myself" both inside and outside the poem. After publishing the volume, Whitman 
wrote anonymous reviews of Leaves of Grass stressing its prophetic, vocal aspects. And within the poem itself, stylistic and thematic techniques are used to highlight speech. These latter have been amply commented upon ${ }^{6}$ and I will simply summarize them here.

1) Whitman explicitly exalts speech, often at the expense of writing-

You shall no longer take things at second or third hand. . .
nor look through the eyes of the dead. . . nor feed on the
spectres in books . . . (1. 35)

This is the breath of laws and songs and behaviour,

This is the tasteless water of souls. ... this is the true sustenance,

It is for the illiterate $\ldots{ }^{8}$

My voice goes after what my eyes cannot reach,

With the twirl of my tongue I encompass worlds and volumes of worlds.

Speech is the twin of 'my vision. ... it is unequal to measure itself. (11. 564-566)

These passages indicate Whitman's trust in the unmediated power of speech. They also disclose his recognition that writing threatens this power. Because writing separates the author both from his own language and from his audience (who therefore "take things at second or third hand"), writing precludes an immediate communal experience-exactly what Whitman wants to inspire in his readers. Writing puts each reader into his own private study, and so the "truth" of "Song of Myself" becomes fragmented in solipsistic, idiosyncratic interpretations beyond the author's control. To preserve and share the experience of "Song of Myself," Whitman must return to a speakeraudience relation, where the "breath of laws and songs and behavior," under the auspices of the governing source of inspiration, can be passed between one another without corruption. Because speech springs up naturally and immediately from experience without prescription or regulation by technics or propriety (which, as conventional, can change through history), speech can make claims to universality. It "encompass[es] volumes of worlds" (and books). It takes place with the fact while writing takes place after the fact, involving a reconstruction of and a separation from presence. ${ }^{9}$ Writing refers to a remembered past, speech inhabits a living present. Speech then becomes Whitman's major tactical motif in "Song of Myself" that harmonizes and consolidates society into a unified "interpretive community." 
2) Whitman uses the simple present and imperative verb tenses-

I celebrate myself . . . (1. 1)

Clear and sweet is my soul ... (1. 52)

Trippers and askers surround me ... (1. 66)

Stop this day and night with me ... (1. 33)

Hear now the tale of a jetblack sunrise . . .10

Failing to fetch me at first keep encouraged . . . (1. 1344)

The simple present rejuvenates the act expressed every time a reader comes across it. The precise economy and bare assertiveness of the simple present give it an immediate impact that the present progressive or the simple past lacks.

The imperatives, less commanding than assuringly inviting, enable Whitman to achieve the kind of attention-grabbing authority a skillful orator exercises upon his listeners.

3) Whitman copiously employs rhetorical questions, anaphora, apostrophes, repetitions (in the catalogues and lists), parallelisms, and other structural techniques-all of which he would have learned from reading textbooks on rhetoric ${ }^{11}$ and are a common characteristic of oral poetry (see Bedient, p. 82)-and Anglo-Saxon and slang diction. As Whitman's career progressed, he inserted more poeticisms (mainly inversions and Latinate diction) in Leaves of Grass and withdrew much of the "language of the street," but the early editions bountifully contain slang words and the above-mentioned stylistic elements which enhance the poem's oracular spontaneity.

The intended effect of these stylistic and thematic motifs is, of course, to make the reader feel (literally, if you will) the presence of Whitman and to force him (or at least coerce him) to respond accordingly. Speech offered Whitman a powerful incantatory pathway undeviatingly into the psyche of his individual readers for, in contrast with the alienating spectatorship of sight, "Only through the umbilicus mundi of dynamic sound could he reconnect his audience with the pagan joy of being" (Bedient, p. 82). Sound raised to the level of the "hum" of the "valvèd voice," the "password primeval," reintegrates "old and young," "maternal as well as paternal," "the wicked just the same as the righteous," into a community of visionaries whose voices are lifted together in a "chant democratic."

And so Whitman desires his readers to view him as the "bard" amalgamating society through the exhilarating attraction of inspired oration. $\mathrm{He}$ exhorts us to amplify these rhetorical strategies beyond the printed page, to affirm an oral presence in the work that transcends visual notations. However, one seemingly insurmountable problem remains: to assert anything more than a mimetic orality (in other words, a non-oral orality) in "Song of 
Myself" or in poetry in general, a reader must ignore the fact that poetry exists for the most part only as signs on a page, not as a living aural presence. For the critic, the vocal origin of the lyric utterance can only be postulated as an ephemeral visionary moment withdrawn (spatially and temporally) behind a veil of written signs - "spectres," to Whitman - that separate as well as unite author and reader. Whether a critic prefers to project himself imaginatively back to the origin of creation, using the text as a lyrical map, so as emphathetically to share the spontaneous vision of the bard; or whether a critic prefers to de-mystify empathy (on both the poet's and the reader's part) by exposing the fallacy of overlooking mediation (as writing) depends upon his presuppositions. Admittedly, these are extremist positions that few critics and teachers of literature actually assume. The fundamental issue here is what becomes of the status of writing under the treatment of Whitman and his recent critics. What is at stake is the condition of writing as mediation and the possibility of an unmediated speech.

Before bringing his discussion of mediation down to the level of linguistic signs, John T. Irwin, in his chapter on Nietzsche and Whitman in American Hieroglyphics, first examines the idea of nature as mediation by opposing realist epistemology to phenomenalist epistemology. Realism argues for common sense assumptions about reality-things are as we perceive them and they have an existence apart from our perception of them. That is, things are self-evident and mediation (in the form of sensation) poses no threat to the steady correspondence of thought and reality. But what happens when one begins to raise thought to self-consciousness by actively doubting the trustworthiness of the senses along with the innocence of consciousness in apprehending reality? The result, as Irwin says, is a "characteristic separation such as presence-to-sight from presence-to-mind, the real from the ideal, the phenomenal from the noumenal" (p. 94), leaving man in a position of epistemological skepticism. In Emerson's famous aphorism, "The axis of vision is not coincident with the axis of things, and so they appear not transparent but opaque." To show the modern relevance of Emerson's statement, Irwin quotes a physicist, Steven Weinberg, ${ }^{12}$ who claims that even anti-metaphysical sciences like current theoretical physics must confront the metaphysical problem of appearance versus reality in trying to formulate a unified field theory. Like the literary critic, the physicist finds himself interpreting an essence (a force, a law, a theory that posits a universal explanation) that manifests itself only in a mediating, phenomenal world of appearances. ${ }^{13}$

The situation of the physicist reading the "Book of Nature" has its analogue in the critic engaged in reading the poem. In the case of "Song of Myself," the critic's "unified field theory" is the author whose coherent, ruling personality stabilizes and elucidates the poem by providing an ultimate referent for its meaning. But instead of a blank, mechanical set of atomic processes to theorize about, the reader of Whitman has a vibrant, congenial "brother" ready to offer interpretive guidance and even demand a sympa- 
thetic rejoinder. Whitman's concern to direct the reader's response is evidenced by open addresses scattered throughout the poem from the first section - "And what I assume you shall assume" (1. 2)-to the last-"I stop somewhere waiting for you" (1. 1346). But to assert his continued though benevolent authority over the reader, Whitman must inject his speaking presence into the poem, and so the problem becomes one of how to bypass the fallen, distancing written signifier, how to convince the reader that "this is no book; / Who touches this, touches a man." 14

The idea that the book can become a coextension of Whitman's physical body which the reader can luxuriate in neatly accords with Irwin's thesis. He extends his hieroglyphic interpretation of "Song of Myself" by claiming that Whitman's desire for contact with the reader goes further than the avowal of presence in the form of speech. Whitman intends to use an even more immediate, self-evident signification with which to gather in his readers in the mutual celebration not only of sonic but also of tactile experience.

The kind of immediately convincing presence that Whitman has in mind is not the presence of a speaking voice but of a physical body ... Whitman's poems are intended to be outlines of the body-hieroglyphic gestures. (Irwin, p. 98)

With the transferral of preferred signs from the oral/aural to the physiognomic/pictographic, Whitman discovers the most impressive means of communication he can find: "Writing and talk do not prove me, / I carry the plenum of proof and every thing else in my face" (11. 579-580). Not in what his face expresses in any linguistic sense, not in any idea which causes a facial expression (the latter then being a mediation, a facade, for an anterior and non-spatial motive), but in his countenance itself. Just as the mute face of nature peremptorily interrupts Whitman's frivolity - "the look of the bay mare shames silliness out of me" (1.244) - so Whitman's patient dumbness thwarts those who would mock him - "With the hush of my lips I wholly confound the skeptic" (1. 581). A mystical silence overrules language.

But, of course, Whitman does use language and he does so in a notation that is never pictographic. So how does Whitman convey his personal physiognomy to the reader other than by proclaiming his silence (an oxymoron), by printing a picture of himself on the title page with no signature (a genuinely pictographic sign but one which is nevertheless incomplete until the figure is named in Section 24), and by repeated sensualistic allusions to his corporeal body (references mediated nonetheless by an arbitrary, abstract, bodiless sign system). Irwin offers a concise yet far-reaching explanation of how Whitman's poetic strategy transmits the visible poetic self to the reader and renders mediation harmless.

First, Whitman makes the poetic self the sole referent of the poem. But since the poetic self is, as Whitman makes clear, a visible self-an inscribed, imaged self constituted by the poem's 
written words - that act makes the poem its own referent. As a result, the absence of the poem's referent is circumvented. (p. 99)

Placing himself(Whitman the poetic self structured in and by language, not Whitman the "real" man in $1855^{15}$ ) at the core of the poem designates anything not assimilated by the poet superfluous (an act which eradicates the mediating role imposed upon the poet by the mimetic preconception of art). The poet can now express himself in all his corporeality - not a world external to himself or a tradition not originating in himself. The reader need look no further for referential meaning than the all-encompassing poet whose egocentric, imperative commands and entreaties alert the reader to his authority and testify to his nearness. Since the poem's content centers around the poetic self, which exists only in and as the poem, "Song of Myself" achieves a self-referential closure without, however, becoming objectified. As opposed to the static, spatial form normally associated with closed, "auto-telic" poems, Whitman's poem is dynamic and personal, temporal and aural, with a unique local subject as its ground. Irwin anticipates the objection that "Song of Myself," with its multifarious characters and events appearing at ostensibly random moments, refers to much more than the poet himself by adding that "in a kind of cosmic consciousness [Whitman] merges the whole universe into that linguistic self" (p. 99): "All these I feel or am" (Whitman, 1. 837). Whitman's inclusive vision absorbs all experience, good and evil, pleasure and pain, into his ever-expanding ego. It only remains for the reader to accept Whitman's heartfelt invitation to join him in this blissful circle of creation:

Do you not see $\mathrm{O}$ my brothers and sisters?

It is not chaos or death. . . it is form and union and plan. . . .

it is eternal life. . . . it is happiness. (11. 1317-1318)

To appreciate the awe-inspiring feat Whitman has performed-charitably bringing poet and reader together in a self-contained poetic world that is nevertheless abundantly prolific and diverse-one must acknowledge the difficulty Whitman faces in the alienating activity of writing. To abolish the absences writing imposes (absence of author from reader, which causes possible misinterpretation; of author from his own creation which continues to function, often in ways the author never intended; of reader from represented, be it the author's conscious intention or the reality he copies), ${ }^{16}$ Whitman instills the poem with his abiding presence, giving to his writing a perpetual liveliness surpassing his own finite earthly life. He lets the language guide his divergent readers to the governing referent of the poem, a convergence settling upon Whitman's bodily text (a textual body, a "corpus").

This is Irwin's conclusion as he moves on to consider Whitman's passion for orality at its most impassioned: opera. What I wish to examine is Irwin's 
thesis that "Song of Myself" exemplifies "that absence of an external referent beyond Whitman's 'inscribed, imaged self that we call self-referentiality" (p. 99). If this is true, then the poetic self stands in an unmediated relation (again, an oxymoron, but I know of no other way to express it) to the world of "Song of Myself," for the poetic self is "Song of Myself." All things in the poem become him and interpretation, on his part, is unnecessary. But several passages indicate that all signs in "Song of Myself" do not begin and end with Whitman, that the poetic self is not the sole referent. These passages imply that, at certain moments, Whitman's situation parallels that of the reader, for Whitman, hardly an archetypal origin or final authority, must himself "read" the universe before passing it on to his audience, the secondary readers.

To me the converging objects of the universe perpetually flow, All are written to me and I must get what the writing means. (11. 404-405)

I wish I could translate the hints about the dead young men and women. (1. 121)

One might interpret these lines as signalling a decline of inspiration or the onset of despair that the poet will eventually surmount, but neither statement reveals a loss of poetic power stylistically and both appear at dramatically uplifting moments. Rather, I would argue that Whitman's insight into the inevitable intervention of writing between the universe, Whitman, "Song of Myself," and the reader, went hand in hand with his belief in the possibility of an oral presence in writing.

Whitman's conception of himself as a reader of the universal text emerges in a key passage near the beginning of "Song of Myself." When a child asks him "What is the grass?" Whitman cannot give him a definite answer, implying that, given the reference to the volume's title, the reader is in a similar position of being unable to totalize "Song of Myself" with a definitive interpretation (using an absolute referent). The answers he does give amount to a kind of suppositional troping activity suggesting that the universal text is pluralistic and poetic.

I guess it must be the flag of my disposition, out of hopeful green stuff woven.

Or I guess it is the handkerchief of the Lord,

A scented gift and remembrancer designedly dropped,

Bearing the owner's name someway in the corners, that we may see and remark, and say Whose?

Or I guess the grass is itself a child. . . . the produced babe of the vegetation.

Or I guess it is a uniform hieroglyphic,

And it means, Sprouting alike in broad zones and narrow zones, 
Growing among black folks as among white,

Kanuck, Tuckahoe, Congressman, Cuff, I give them the same,

I receive them the same,

And now it seems to me the beautiful uncut hair of graves.

Tenderly will I use you curling grass,

It may be you transpire from the breasts of young men,

It may be if I had known them I would have loved them;

It may be you are from old people and from women, and from offspring taken soon out of their mothers' laps,

And here you are the mothers' laps. (11. 101-115)

Although Irwin notes this passage earlier in his book (p. 20), his neglect of it when talking about the aboriginal referent of "Song of Myself" implies that the critic assumes the "grass" to belong to or issue from the grand, cosmic self hovering over the poem. But, then, why do the "leaves" have to be read? Must Whitman "translate" the "writing" of nature only because his readers do not yet share his unmediated vision? Perhaps this may be the case, especially considering the poem's conclusion. But I don't know if a clear choice can be made between viewing Whitman as the inspired bard with immediate access to the truth or viewing him merely as a privileged reader closer to the truth but mediated nonetheless. What is most important is that, in his willingness to produce several possible tropic readings of the "uniform hieroglyphic," Whitman adheres to an anti-dogma that levels beliefs to the aesthetic plane of interpretation with the poet as inspired mediator and interpreter.

\section{II.}

And I swear I never will translate myself at all, only to him or her who privately stays with me in the open air.

-Whitman, "Song of Myself"

For poetry was all written before time was, and whenever we are so finely organized that we can penetrate into that region where the air is music, we hear those primal warblings and attempt to write them down, but we lose ever and anon a word or a verse and substitute something of our own, and thus miswrite the poem.

-Emerson, "The Poet"

I find letters from God dropped in the street and every one is signed by God's name.

And I leave them where they are, for I know that others will punctually come forever and ever.

-Whitman, "Song of Myself"

We know that the secret of the world is profound, but who or what shall be our interpreter, we know not. A mountain ramble, a new style of face, a new person, may put the key into our 
hands. Of course the value of genius to us is in the veracity of its report. Talent may frolic and juggle; genius realizes and adds.

-Emerson, "The Poet"

"[T]he veracity of its report." But do not the additions of genius falsify the "report"? If the right interpreter translates God's "letters . . . punctually" (punctuatingly?) for his community of readers gathered "in the open air," then the "secret of the world" is revealed by his consequent hieroglyphic (an authentic "priestly writing") whose verity is self-evident. But if he "lose[s] ever and anon a word or a verse and substitute[s] something of [his] own," then his readers are saddeningly confronted with yet another fragmentary, eccentric version of the "secret." Unless, that is, the poet has privileged access to the "secret" and his version stems immediately from it. But how does he convince his readers of his election into the sacred circle of prophets other than by stating, as Whitman does with imposing simplicity, "There is that in me ..." (1. 1309)? How does the visionary prophet consecrate his language and accumulate an assenting audience who credits his inspiration?

As we have seen, one way for the poet to assemble followers is through the incantatory, oracular power of his words, but this conclusion only begs the question of how language actually acquires oracular power. Other than rhetorical patterns (which have nothing mysterious about them), what is it that distinguishes prosaic, discursive language which may enlighten but does not elate its reader, from rhapsodic, divinely charged poetic language which enthralls the reader with orphic affections of presence?

In searching for a description of Whitman's proselytizing method, C. Carroll Hollis, in Language and Style in "Leaves of Grass,"turns to the "ordinary language" philosopher John Austin's theory of speech acts. Like most critics, Hollis begins by noting Whitman's lifelong interest in oratory, but he soon moves into theoretical discussions of style, basing his arguments on such well-known theorists of language as Searle and Jakobson as well as Austin. In relation to the present issue, Austin's terminology comes in handywhat makes Whitman's language so effectively oracular, says Hollis, is its "illocutionary force." As Austin defines it, an illocutionary act is that kind of utterance which performs the very act that it represents. ${ }^{17}$ For example, when the queen says "I christen this ship the Queen Elizabeth" and then smashes a champagne bottle against the ship's prow, her statement is an integral part of the act of christening, not merely a statement about the christening. Because saying and doing are united in illocutionary acts, language's usual role as the outward representation of action is ruled out. Language itself becomes active, alive, capable of working rather than simply imitating work.

Besides obviating the mediating status of language (as it functions in representaton) by making language performative, illocutionary acts also presuppose a cooperative, familiar relationship between speaker and listener. Austin's "felicity rules" (behavioral conventions that render possible and suc- 
cessful an illocutionary act) state that "(B.1) The procedure must be executed by both participants both correctly and (B.2) completely" (p. 15). In other words, the two parties must fulfill prescribed expectations for an illocutionary act to be complete. Thus, in illocutionary contexts, language functions as a contractual vehicle unifying speaker and listener in a shared experience. Just as illocutionary acts merge language and action by making the saying of something the doing of something, so they also merge speaker and listener by involving at least two people in their performative requirements. With "the immediacy of present-time involvement and the inclusion of the audience addressed" (Hollis, p. 83), illocutionary acts provide Whitman with a stylistic channel open to the prophetic force he wishes to convey in his poetry.

Whitman resorts to an illocutionary mode, then, because it joins the speaker of the language, the referent of the language, and the receiver of the language, together in a (in the case of "Song of Myself") fervent, reverberating "barbaric yawp" executing and embodying Whitman's visionary desires. To prove Whitman's widespread illocutionary practice in the early poetry, Hollis uses Searle's taxonomy of performative statements (which refine Austin's labels into "assertives," "directives," "commissives," "expressives," and "declaratives") ${ }^{18}$ and provides numerous passages from "Song of Myself" that exemplify each category. Through a scrupulous grammatical study of Whitman's syntax (especially his verbs) and rhetorical figures, supported by statistical counts, Hollis makes a firm, compelling case for Whitman's illocutionary technique. But when Hollis concludes his stylistic discussion and begins to examine the theoretical implications of finding speech acts in literature, he runs up against a problem Austin wisely avoided: what happens when an illocutionary act is written down, particularly in a literary context? Do the "felicity rules" which validate a performative speech act still apply to or are they broken by performative "written acts"?

If we begin with Austin, the answer is "No"-illocution is not a quality of literary language.

... a performative utterance will, for example, be in a peculiar way hollow or void if said by an actor on the stage, or if introduced in a poem, or spoken in a soliloquy. (p. 22)

Because he merely transmits someone else's already performed illocutionary act (granting that literary creation may be conceived in this way), an actor's words have no immediate illocutionary force. And in a poem, where "the normal conditions of reference may be suspended, or no attempt made at a standard perlocutionary act, no attempt to make you do anything, as Walt Whitman does not seriously incite the eagle of liberty to soar" (Austin, p. 104), illocutionary force also dissolves, for the listeners, acknowledging the fictionality and "insincerity" of poetry instead of becoming coacting participants, become disinterested spectators with no compulsion to act. And in 
soliloquy (which characterizes all writing), the perlocutionary element of the speech act-the effect it immediately has upon an audience-disappears altogether. To Austin, written poetry has little to do with speech acts. ${ }^{19}$

Literary criticism has accepted Austin's challenge and addressed the possibility of using speech act theory to analyze poems. Hollis tries to rescue poetry from Austin's exclusion by referring to Richard Ohmann's essay "Speech Acts and the Definition of Literature," 20 a forthright attempt to define literary language using a speech act terminology. Hollis considers Ohmann's argument the most significant effort at conjoining analytic philosophy, which prides itself on its dismissal of literary discourse, and literary studies. Despite Austin's warning, Ohmann does formulate a definition of literature using illocutionary concepts (a definition, strangely enough, Austin would have approved of):

I am ready to set down the first approximation of a definition: a literary work is a discourse abstracted, or detached, from the circumstances and conditions which make illocutionary acts possible; hence it is a discourse without illocutionary force. (p. 13)

Ohmann prefaces his definition by enumerating the "circumstances and conditions" necessary to illocution which are absent from literary contexts: 1 ) the lack of a specified, unambiguous speaker -is it the author who is speaking or merely a projected persona whom the author may judge ironically?; 2) the lack of an explicit, manifest referent -are these actual experiences or existent things the speaker is reporting or do they exist only in his fancy?; 3) the lack of a transparent, satisfactory language - tropes such as irony, metaphor, symbol, and so on, disrupt the denotative functions of language and require reconstruction by the reader in order for them to represent properly; and 4) the lack of a limited, established audience who responds according to the desired perlocutionary act-along with his sympathetic, admiring readers, Whitman also has cynical readers, who reject him, and smug readers, who parody him. And so, as opposed to the genuine illocutionary act which involves a willful personality with obvious intentions, an identifiable referent submitted to predication in a straightforward, unequivocal language, and a knowing listener, a literary context involves an ambivalent persona with disguised intentions, a fictional referent constructed out of an oblique, figurative language, and, in general, an alien (culturally and historically) audience. With these shifting conditions of communicability, literature tends to destabilize the contextual requirements of an illocutionary act.

This conclusion, based upon the mediations imposed by writing, counteracts Hollis's reading of Whitman, leaving one guessing as to why Hollis appeals to Ohmann for theoretical support. Ohmann expressly defines literature as that unique "conventional setting" (p. 9) which excludes the illocutionary aspects of its sentences. Hollis distinguishes Whitman's poetry (which he openly reveres, as do I) categorically for its illocutionary force. Oh- 
mann, however, modifies his definition one page later with an addendum which means "literature does not have to be rejected" (Hollis, p. 76) and renders his argument serviceable to Hollis.

Let me supplement the definition: A literary work is a discourse whose sentences lack the illocutionary forces that would normally attach to them. Its illocutionary force is mimetic. (Ohmann, p. 14)

In other words, literature is not an illocutionary act-it imitates an illocutionary act. Despite Austin's claim that "Language in such [literary] circumstances is in special ways-intelligibly-used not seriously" (p. 22), and hence breaks a "felicity rule," literature can still represent a performative act. It can signify an illocutionary motive which induces the "reader to imagine a speaker, a situation, a set of ancillary events, and so on" (Ohmann, p. 14), even though they have no eventful existence beyond the printed page. With this qualification, then, speech act theory can be applied to literature and Hollis's implementation of it is justified.

But representing an illocutionary act brings about the mitigation of its original illocutionary force (Austin distinguishes "force," which is immediate, from "sense and reference," which are representational, on page 100). Illocutionary force proceeds spontaneously out of a particular situation hemmed in by the conditions of presence (of speaker to listener to referent). Sunder the conventional requirements by detaching the utterance from its natural setting and placing it in a fictional context ${ }^{21}$ and the act itself becomes fictional and groundless. Without a "real," natural context (although one determined by convention) to guarantee a "serious" speaker and to ensure a desired response, illocutionary force, in literature, becomes merely an empty, impotent abstraction. Illocutionary acts are those which lose their meaning in representation.

The necessary representationality of illocution in literature, with the consequent loss of force, added to the other attenuations I have mentionedthe absence of a real "I," a present, sincere "utterance-origin"(Austin, p. 60); the absence of a specified, appropriate audience to complete the act; and the absence of a proximate, circumscribed referent understood by both parties forfends the qualification of any literature as illocutionary. The separations and distances of written discourse, the mediations inherent in the writing and reading processes, tend to rob language of its immediate power, oracular or otherwise. What Whitman wanted most he could not have. And he knew it. For "Song of Myself" ends not with a mystical joining of speaker and listener but with an anticipation of "form and union and plan" finally realized ... well, "somewhere"-but not in the writing.

The University of California, Los Angeles 


\section{NOTES}

1 Chapter 2 of In Re Walt Whitman, "Walt Whitman and His Poems," contains reviews of the first edition of Leaves of Grass written anonymously by Whitman himself. A short sample of his prose reveals how Whitman wished to be understood.

An American Bard at last! (p. 13)

... his voice bringing hope and prophecy to the generous races of young and old. (p. 13)

... talking like a man unaware that there was ever hitherto such a production as a book, or such a being as a writer. (p. 14)

If in this poem the United States have found their poetic voice ... (p. 21)

These passages, some of which are quoted by Hollis, indicate Whitman's desire to be heard, not simply read. See In $R e$, edited by his literary executors, Horace L. Traubel, Richard Maurice Bucke, and Thomas B. Harned. Folcroft Library Edition, 1973 (first published, Philadelphia: David McKay, 1893), pp. 13-21.

2 Selecting a time period at random, I counted 13 entries from 1970-1974 whose titles refer specifically to "voice" or "song." See Donald D. Kummings, Walt Whitman, 1940-1975: A Reference Guide (Boston: G.K. Hall \& Co., 1982).

3 Two early biographical studies are Lionel Crocker's "Walt Whitman's Interest in Public Speaking," Quarterly fournal of Speech, 26 (December, 1940), 657-667; and F.O. Matthiesson's chapter on "Oratory" in American Renaissance (New York: Oxford University Press, 1941).

4 Examples of this type are M. L. Rosenthal's "Music of Awareness: Association and Feeling," in Poetry and the Common Life (New York: Oxford University Press, 1974); and D. R. Jarvis's "Whitman and Speech-Based Prosody," Walt Whitman Review, 27 (June, 1981), 51-62.

5 John T. Irwin, American Hieroglyphics (New Haven: Yale University Press, 1980); Calvin Bedient, "Orality and Power (Whitman's 'Song of Myself)," Delta: Revue de Centre d'Etudes et de Recherche sur les Ecrivains du Sud aux Etats-Unis, 16 (May, 1983), 79-94; C. Carroll Hollis, Language and Style in "Leaves of Grass" (Baton Rouge: Louisiana State University Press, 1983).

6 For example, Donald Kummings, "Whitman's Voice in 'Song of Myself': From Private to Public," Walt Whitman Review, 17 (March, 1971), 10-16; Galway Kinnell, "Whitman's Indicative Words," American Poetry Review, 2 (March-April, 1973), 9-10; C. Carroll Hollis, "Rhetoric, Elocution, and Voice in Leaves of Grass," Walt Whitman Quarterly Review, 2 (Fall, 1984), 1-27.

7 All Whitman quotations are taken from Leaves of Grass: ATextual Variorum of the Printed Poems, 3 vols. Edited by Sculley Bradley et al. (New York: New York University Press, 1980). I have quoted the 1855 versions.

8 These lines were deleted after 1871. Originally, they appear between lines 360 and 361 . 
9 I take my usage of "presence" from Derrida's complex definition of it as the "transcendental signified" governing the play of signifiers and acting as their ultimate referent. See Of Grammatology, translated by Gayatri Chakravorty Spivak (Baltimore, MD: Johns Hopkins University Press, 1974), p. 12; also, Writing and Difference, translated by Alan Bass (Chicago: University of Chicago Press, 1978), pp. 278-280.

10 This line, deleted after 1856, appears between lines 874 and 875 .

11 Whitman's familiarity with books on oratory and rhetoric has been revealed by both Hollis and William L. Finkel in "Walt Whitman's Manuscript Notes on Oratory," American Literature, 22 (March, 1950), 29-53.

12 The book Irwin quotes from is Weinberg's The First Three Minutes: A Modern View of the Origin of the Universe (New York: Basic Books, 1977).

13 I am not arguing that science does not improve upon itself or that the progress of knowledge in history is merely one of one interpretation supplanting another without any significant advance toward "truth." I only wish to point out that modern physics must confront mediation just as the literary critic does.

14 From "So Long" (11. 53-54, 1860 edition).

15 None of the critics I am discussing naively assumes the speaker of the poem is anything more than a linguistically constructed persona who strongly asserts a personality.

16 One elaborate theoretical discussion of literature and mediation is Murray Krieger's "Mediation, Language, and Vision in the Reading of Literature," in Poetic Presence and Illusion (Baltimore, MD: Johns Hopkins University Press, 1979).

17 John Austin, How to Do Things With Words. 2nd edition, edited by J. O. Urmson and Marina Sbisa (Cambridge, MA: Harvard University Press, 1975).

18 John Searle, Expression and Meaning: Studies in the Theory of Speech Acts (Cambridge, England: Cambridge University Press, 1979), 12-17.

19 Austin writes of poetic language, "These references to 'use of language' have nothing to do with the illocutionary act" (p. 104).

20 The essay appears in Philosophy and Rhetoric, 4 (Winter, 1971), 1-19.

21 On the distinction between "natural discourse" and "fictive discourse," see Barbara Herrnstein Smith's On the Margins of Discourse, The Relation of Literature to Language (Chicago: University of Chicago Press, 1978). 